This is a revised personal version of the text of the final journal article, which is made available for scholarly purposes only, in accordance with the journal's author permissions. The full citation is:

Charles J. Banks, Michael Chesshire, Sonia Heaven, Rebecca Arnold, Anaerobic digestion of source-segregated domestic food waste: Performance assessment by mass and energy balance, Bioresource Technology, Volume 102, Issue 2, January 2011, Pages 612-620, ISSN 0960-8524, 10.1016/j.biortech.2010.08.005.

(http://www.sciencedirect.com/science/article/pii/S0960852410013404)

\title{
Anaerobic digestion of source segregated domestic food waste: performance assessment by mass and energy balance
}

\section{Author names and affiliations}

\author{
Charles J Banks ${ }^{\mathrm{a}^{*}}$, Michael Chesshire ${ }^{\mathrm{b}}$, Sonia Heaven ${ }^{\mathrm{a},}$ Rebecca Arnold $^{\mathrm{b}}$ \\ ${ }^{\text {a }}$ School of Civil Engineering and the Environment, University of Southampton, \\ Southampton SO17 1BJ, UK \\ ${ }^{\mathrm{b}}$ BiogenGreenfinch, The Business Park, Coder Road, Ludlow SY8 1XE, UK
}

\begin{abstract}
An anaerobic digester receiving food waste collected mainly from domestic kitchens was monitored over a period of 426 days. During this time information was gathered on the waste input material, the biogas production, and the digestate characteristics. A mass balance accounted for over $90 \%$ of the material entering the plant leaving as gaseous or digestate products. A comprehensive energy balance for the same period showed that for each tonne of input material the potential recoverable energy was $405 \mathrm{kWh}$. Biogas production in the digester was stable at $642 \mathrm{~m}^{3}$ tonne $\mathrm{e}^{-1} \mathrm{VS}$ added with a methane content of around $62 \%$. The nitrogen in the food waste input was on average $8.9 \mathrm{~kg}_{\text {tonne }}{ }^{-1}$. This led to a high ammonia concentration in the digester which may have been responsible for the accumulation of volatile fatty acids that was also observed.
\end{abstract}

\section{Keywords}

Anaerobic digestion, food waste, energy, biogas, methane, mass balance

\section{$1 \quad$ Introduction}

Many examples exist of the use of anaerobic digestion (AD) to treat the mechanically separated biodegradable fraction of municipal waste. Both 'wet' and 'dry' anaerobic technologies have been used as part of mechanical-biological treatment (MBT) (MataAlvarez, 2003). There are also examples of the processing of mixed source segregated biodegradable wastes such as kitchen and garden wastes (Archer et al., 2005); but there are few reports of $\mathrm{AD}$ plants operating entirely on source segregated household food waste.

\footnotetext{
* Corresponding author: Tel +44 (0)2380 594650, fax 677519, email cjb@ soton.ac.uk
} 
Interest in this approach is growing within Europe due to rising energy costs associated with the processing of wet waste, the requirement to meet the diversion targets of the EU Landfill directive (99/31/EC), and the need to comply with regulations for the disposal of animal byproducts (EC 1774/2002). When AD is used to process source segregated waste it not only produces biogas, but also presents an opportunity to recover additional value from the waste material, in the form of a quality assured nutrient-rich fertiliser product that can applied to agricultural land used in food production. If the waste is not source segregated and the organic fraction is recovered through a MBT plant, regulations in many European countries do not permit the digestate product to be used on land in this way (Stretton-Maycock and Merrington, 2009). Consequently, there is strong interest from government and industry in methods of processing source segregated household food waste by the anaerobic digestion route.

There are, however, reasons why food waste has not been popular in the past as a single substrate, since digestion of this energy-rich material can lead to operational problems. The protein content of food waste typically gives a high nitrogen content on hydrolysis, which leads to elevated concentrations of ammonia or ammonium ion in the digester. The distribution of the two species and their relative toxicity is $\mathrm{pH}$ dependent, with the more toxic form dominating at higher $\mathrm{pH}$ (Mata-Alvarez, 2003). There is still uncertainty concerning the concentration at which ammonia becomes inhibitory to methanogenesis, and this is reflected in the various limit values given in recent literature. According to Mata-Alvarez (2003), inhibition occurs at total ammonia concentrations of $1200 \mathrm{mg} \mathrm{l}^{-1}$ and above. Hartmann and Ahring (2005) showed ammonia inhibition begins at free ammonia concentrations above 650 $\mathrm{mg} \mathrm{l}^{-1} \mathrm{NH}_{3}-\mathrm{N}$, whereas Angelidaki et al. (2005) in a study of 18 full-scale biogas plants in Denmark co-digesting manure and organic waste only found decreases in efficiency when total ammonia was above $4000 \mathrm{mg} \mathrm{NH}_{3}-\mathrm{N} \mathrm{l}^{-1}$. El Hadj et al. (2009) found that methane generation in batch tests with a high-protein synthetic biowaste under mesophilic conditions fell by $50 \%$ at ammonium ion concentrations of $3860 \mathrm{mg} \mathrm{NH}_{4}{ }^{+}-\mathrm{N}^{-1}$. Although ammonia has been shown to create operational difficulties in anaerobic digesters, it is also recognised that populations can acclimate, making it difficult to predict the exact concentration at which process instability or failure may occur (Fricke et al., 2007). It has been reported on a number of occasions that digestion at high ammonia concentrations can give stable biogas production at alkaline $\mathrm{pH}$ over extended periods of time under continuous loading conditions. In digesters treating food waste these conditions can also lead to operation at elevated levels of volatile fatty acids in the digestate (Banks et al., 2008, Neiva Correia et al., 2008). Similar conditions have been reported in thermophilic cattle slurry digesters (Neilsen and Angelidaki, 2008), and in other nitrogen rich substrates such as slaughterhouse waste (Banks and Wang, 1999, Wang and Banks 2003).

The current work presents the results of a mass and energy balance over a 14-month period for a full-scale food waste digester operating at high ammonia and VFA concentrations.

During the study period the digester was fed mainly on food waste collected from domestic properties mixed with small amounts of commercial food waste and municipal green waste. Since the study was completed the plant has continued to operate successfully as a commercial facility processing food waste.

\section{Materials and Methods}

\subsection{Digestion plant}


The plant was commissioned in March 2006 and for the first 9 months of operation was fed on mixed kitchen and garden waste collected from domestic properties. From January 2007 the feed was gradually switched to source segregated food waste only. The study period began on 1 June 2007 (day 0), and data for the mass and energy balances was collected for 426 days. During the study 3,936 tonnes of waste were processed of which $95.5 \%$ was source-segregated domestic food waste, with the remainder consisting of commercial food waste from restaurants and local businesses (2.9\%) including a small amount of whey, and grass cuttings $(1.6 \%)$. The food waste received at the plant was first shredded in a rotary counter-shear shredder to reduce the particle size, then passed to a feed preparation vessel where it was mixed with recirculated whole digestate and macerated to give a particle size less than $12 \mathrm{~mm}$. The feed to the digester was via a buffer storage tank providing 3 days' storage, to allow continuous feeding over weekends and public holidays. The digester itself was a $900 \mathrm{~m}^{3}$ tank that was completely mixed by continuous gas recirculation and maintained at $42{ }^{\circ} \mathrm{C}$ by external heat exchangers: the choice of temperature was based on the previous experience and preference of the plant operator. The digestate was passed batch-wise to a pasteurisation tank $\left(60 \mathrm{~m}^{3}\right)$ where it was heated to $70{ }^{\circ} \mathrm{C}$ for a minimum of 1 hour. Pasteurised digestate was transferred to the digestate storage tank $\left(900 \mathrm{~m}^{3}\right)$, where it was kept until being exported to local farms for use on agricultural land as either separated fibre, liquor or whole digestate. The biogas generated was used to produce electricity using a $195 \mathrm{~kW}$ MAN Combined Heat and Power (CHP) unit with an assumed electrical conversion efficiency of $32 \%$ at full load and a potential for $53 \%$ recovery of heat via the jacket and exhaust cooling water streams. Electricity produced by the CHP and imports and exports to the grid were all metered. The power requirements of the plant were calculated from (CHP generator meter + grid import meter - grid export meter). Some of the heat produced by the CHP was fed back into the process. Temperatures in all tanks were recorded continuously using a SCADA. More detailed descriptions of individual components of the plant are given in Chesshire (2007) and Arnold et al. (2010).

\subsection{Sampling, measurement and analysis}

Quantification of input waste and other materials. All vehicles delivering waste to the plant were weighed on a weighbridge before and after discharging their load. The origin and type of waste was recorded. Water usage was monitored by separate meters, one for the industrial process water and another for staff facilities (e.g. toilets and washrooms).

Biogas sampling analysis and quantification. A biogas sample was taken daily from the gas holder feeding the CHP and analysed for methane and carbon dioxide content using a GA2000 portable infrared gas analyser (Geotechnical instruments, Leamington Spa, UK). Biogas volumes were recorded on an industrial gas flow meter, and readings were manually adjusted for water vapour content and expressed at standard temperature and pressure (STP) of $273.15 \mathrm{~K}$ and $101.325 \mathrm{kPa}$.

Waste input sampling and analysis. Daily composite samples of the shredded feedstock were taken for analysis of the total solids (TS) and volatile solids (VS) content according to Standard Method 2540 G (APHA, 2005). Further composites were prepared from the daily composites over 2-week periods for determination of Total Kjeldahl Nitrogen (N), phosphorus (P), and potassium (K). Total Kjeldahl $\mathrm{N}$ was determined using a Kjeltech block digestion and steam distillation unit according to the manufacturer's instructions (Foss Ltd, Warrington, UK). Samples for Potassium and Phosphorus were extracted using concentrated $\mathrm{HNO}_{3}$ in a CEM Microwave Accelerated Reaction System for Extraction (MARSX) (CEM 
Corporation, North Carolina, USA). Potassium was quantified using a Varian Spectra AA200 atomic absorption spectrophotometer (Varian, Australia) according to the manufacturers' instructions. Phosphorus was measured spectrophotometrically by the ammonium molybdate method (ISO 6878: 2004).

Digester and digestate sampling and analysis. Samples of digestate were taken on a regular basis for analysis. Total and volatile solids were measured as above. Ammonia was determined using a Kjeltech steam distillation unit according to the manufacturer's instructions (Foss Ltd, Warrington, UK). VFA were quantified in a Shimazdu GC-2010 gas chromatograph, using a flame ionization detector and a capillary column type SGE BP-21 with helium as the carrier gas at a flow of $190.8 \mathrm{ml} \mathrm{min}^{-1}$, with a split ratio of 100 giving a flow rate of $1.86 \mathrm{ml} \mathrm{min}^{-1}$ in the column and a $3.0 \mathrm{ml} \mathrm{min}^{-1}$ purge. The GC oven temperature was programmed to increase from 60 to $210{ }^{\circ} \mathrm{C}$ in $15 \mathrm{~min}$, with a final hold time of $3 \mathrm{~min}$. The temperatures of injector and detector were 200 and $250{ }^{\circ} \mathrm{C}$, respectively. Samples were prepared by acidification in $2 \%$ formic acid. A standard solution containing acetic, propionic, iso-butyric, n-butyric, iso-valeric, valeric, hexanoic and heptanoic acids, at three dilutions giving individual acid concentrations of 50, 250 and $500 \mathrm{mg} \mathrm{l}^{-1}$ respectively, was used for calibration. Alkalinity was measured by titration using $0.25 \mathrm{~N} \mathrm{H}_{2} \mathrm{SO}_{4}$ to endpoints of 5.7 and 4.3 (Ripley et al., 1986). Digestate $\mathrm{pH}$ was measured using a combination glass electrode and meter calibrated in buffers at $\mathrm{pH} 4,7$ and 9.

\section{$3 \quad$ Results and discussion}

\subsection{Feedstock characteristics, organic loading rate and retention time}

Figure 1 shows values for TS and VS throughout the study period for the domestic food waste and the commercial food waste (not including whey) components of the feedstock. The average solids content was similar for domestic food waste (TS 27.7\%, VS 24.4\%) and commercial food waste (TS 27.8\%, VS 24.3\%). As can be seen in Figures 1a and b, there was some variation in the TS and VS content of individual samples of domestic food waste but no strong evidence of seasonal variation and the VS:TS ratio remained fairly constant. Figure 1c shows the TS and VS values for commercial food waste: these spanned a greater range than for the domestic food waste, reflecting greater differences in moisture content, but again the ratio of VS:TS was consistent.

The average nutrient content of the domestic food waste during the study period was 8.9, 1.9 and $3.3 \mathrm{~kg}$ tonne $\mathrm{e}^{-1}$ on a wet weight (WW) basis for Total Kjeldahl Nitrogen (TKN), Phosphorus $(\mathrm{P})$ and Potassium $(\mathrm{K})$ respectively, while the equivalent values for commercial food waste were 8.7, 1.8 and $3.4 \mathrm{~kg}$ tonne $\mathrm{e}^{-1} \mathrm{WW}$. Figure 2a shows the variability in fortnightly composite samples of domestic food waste. The variations between consecutive samples may reflect the fact that only a small amount of material is ultimately used in laboratory analysis, and however much effort is made to prepare representative composites, subsamples may show slight non-homogeneity due to unavoidable scale factors.

The average organic loading rate during the study period was $2.5 \mathrm{~kg} \mathrm{VS} \mathrm{m}^{-3} \mathrm{day}^{-1}$ based on the nominal digester volume of $900 \mathrm{~m}^{3}$, or $2.7 \mathrm{~kg} \mathrm{VS} \mathrm{m}^{-3}$ day $^{-1}$ based on the average volume of digester contents. The maximum and minimum weekly average loadings based on actual volume were 3.46 and $0.91 \mathrm{~kg} \mathrm{VS} \mathrm{m}^{-3}$ day $^{-1}$ respectively, with the minimum corresponding to a Christmas closure period. The average hydraulic retention time was 80 days, based on the 
nominal digester volume divided by the mass input on a wet weight basis. More detailed information on day-to-day variations in feedstock quantities is given in Arnold et al. (2010).

\subsection{Digestate characteristics}

Values for TS and VS content of digestate and fibre throughout the study period are shown in Figure 3. The average solids content was TS $4.5 \%$, VS $2.9 \%$ for the digestate and TS $23.8 \%$, VS $17.9 \%$ for the fibre. As can be seen in Figure 3, there was some variation in the TS and VS content of individual samples of digestate but the VS:TS ratio remained fairly constant.

The average nutrient content of the digestate during the study period was $5.6,0.4$ and $2.3 \mathrm{~kg}$ tonne $^{-1} \mathrm{WW}$ for TKN, $\mathrm{P}$ and $\mathrm{K}$ respectively. Figure $2 \mathrm{~b}$ shows the variability between fortnightly composite samples. As expected the values were more consistent than those for feedstock, apart from one high value for nitrogen in day 215-227. A nutrient mass balance taking into account water additions showed outputs equal to $86.1 \%, 32.8 \%$ and $96.4 \%$ of the input values of TKN, $\mathrm{P}$ and $\mathrm{K}$ respectively. The lower recovery of TKN and particularly of $\mathrm{P}$ may indicate losses by precipitation e.g. of struvite $\left(\mathrm{NH}_{4} \mathrm{MgPO}_{4} \cdot 6 \mathrm{H}_{2} \mathrm{O}\right)$ within the digester system.

\subsection{Biogas output and variability}

Table 1 shows the total biogas production and the proportion of methane and carbon dioxide based on daily measurements. The specific biogas and methane yields are given on both a wet weight and a VS basis, and show the food waste has a high methane potential in comparison to typical municipal residual waste streams. The high moisture content means, however, that the biogas production per tonne of imported material is similar to typical values reported for municipal solid waste (MSW). Volumetric gas production is calculated based on the volume of the digester only.

Variability in the biogas production and composition is shown by reference to the weekly values for methane, carbon dioxide and biogas in Figure 4a. Total biogas production over a 1week period varied from a minimum $6,364 \mathrm{~m}^{3}$ to a maximum of $13,438 \mathrm{~m}^{3}$, although some of the peaks and troughs can be explained by differences in the incoming load (e.g. suspension of some deliveries during the Christmas - New Year period in 2007). Figure 4b shows the variability in methane concentration based on daily readings, compared to the calculated average for the whole study period.

\subsection{Digestion parameters}

Digestion parameters are reported from day 0 corresponding to the start of the mass and energy balance study, although measurement of VFA and ammonia only began some time after this.

The average digester $\mathrm{pH}$ in the study period was 8.13 with values remaining mainly between 8.0-8.25 (Figure 5a). From day 252 to day 304, however, the pH rose to 8.64, then fell sharply to a minimum value of 7.24 by day 342 . This fall appears to have been a result of a shift in alkalinity, with an increase in intermediate alkalinity (IA), a fall in partial alkalinity (PA) and a rise in the IA/PA ratio to 2.74 (Figure 5b). Prior to this the IA/PA ratio was around 0.4 indicating stable operation (Ripley et al., 1986). 
The major factor affecting the intermediate alkalinity is the concentration of undissociated VFA. This fell between day 250-300, with a decrease in the propionic acid concentration, followed by a rapid increase after day 300 in both acetic and propionic acid and a slower rise in the concentration of butyric etc (Figure 5c). The reasons for this change are not clear but the ammonia concentration in the digesters had been increasing steadily and reached around $5000 \mathrm{mg} \mathrm{l}^{-1}$ at this time. Subsequent work in laboratory-scale digesters has suggested that high ammonia concentrations may cause a shift in the biochemical pathways leading to methane formation (Banks and Zhang, 2010). A slight decrease in biogas methane concentration can be seen before day 342 followed by recovery. Total VFA concentrations continued to increase and approached $15000 \mathrm{mg} \mathrm{l}^{-1}$ by the end of the monitoring period, of which propionic acid made up 11,500 $\mathrm{mg}^{-1}$. Despite the high VFA values the specific and volumetric biogas yields remained unaffected (Figure 6).

\subsection{Overall mass balance}

The mass balance around the plant was calculated in two ways: by wet weight (Table 2) and on a VS basis (Table 3). In the wet weight balance water additions from both the process and facilities supplies were included as inputs. Methane and carbon dioxide volumes were corrected to STP and it was assumed that the spot values for methane concentration are representative of a 24-hour period. Weights of digestate, fibre and rejects were taken from weighbridge data for materials leaving site. Stored materials are based on tank volumes and estimated quantities of fibre in the digestate hall. Weight data on all wastes generated by the operation (including canteen wastes and litter as well as feedstock contamination) was only collected from April 2008, and therefore underestimates the total weight of material leaving the plant by this route. Contamination of the feedstock itself, assessed by hand sorting of samples (not reported here), was minimal. Evaporative water losses from the gas mixing system due to supersaturation followed by condensation in the gas holder were not taken into account. Calculations also did not consider fugitive emissions of gas or liquid from the site.

For the VS mass balance, the VS of input food waste, digestate and fibre was based on the average of all laboratory determinations for each parameter. The VS of the reject stream was taken as equal to that of the incoming food waste. The amount of material stored in tanks was based on tank volumes and an assumed VS equal to the digestate storage. Calculations using a 21-day rolling average of VS values for input food waste and digestate gave similar results, with only a slight change in the overall mass balance from $90.3 \%$ (Table 3 ) to $90.6 \%$.

The method for determination of VS leads to volatilisation and loss of intermediate soluble metabolites such as VFA and ammonia. If concentrations of these in the liquid digestate are taken into account and assumed to be vaporised during the standard analytical procedure, the VS mass balance increases to $95.7 \%$.

Considering the difficulties of obtaining representative samples from very heterogeneous materials, the results of the mass balance are considered to be acceptable for a full-scale plant.

Figures $6 \mathrm{a}$ and $\mathrm{b}$ show the mass balance plotted on a weekly and cumulative weekly basis. On a weekly basis (Figure 6a) there is some variability, a proportion of which can be attributed to the problem of estimating the quantities of digestate and fibre stored on site. From Figure $6 \mathrm{~b}$ it can be seen that at the point when materials were last taken off site and 
accurate weights recorded, the difference between input and output weights without consideration of storage was only 190 tonnes out of a total input of 4,823 tonnes (4\%).

\subsection{Gross electricity and heat outputs from the CHP unit}

Values for electricity and heat outputs during the study period from the CHP unit only are shown in Table 4. There was no way of to measure directly the heat output associated with the CHP or the amount of this heat that used to maintain the temperature of the digestion plant. The calculated gross energy output of the CHP plant was 2,781 MWh which at a recovery value of 53\% would provide a further 1,474 MWh of energy in the form of extractable heat, in addition to the electrical energy output.

When starting the CHP unit, a small amount of natural gas was used before switching to biogas. During the study period this totalled $1,534 \mathrm{~m}^{3}(0.4 \%$ of the total methane production of the plant). No electricity was generated as a result and this component is therefore not included in Table 5, but is taken into account in the overall energy balance.

At the time when the CHP unit is not generating electricity, due to scheduled maintenance, breakdown, or gas quality below the threshold limit, the biogas is burnt in a separate boiler unit to produce hot water.

\subsection{Electricity and heat requirements of the process plant}

Electrically-powered equipment involved in operation of the plant included the raw waste shredder, macerators, feed pumps, biogas compressor pumps, CHP and boiler water feed pumps, belt press, air filtration and minor ancillary equipment such as conveyors. The primary consumers of electricity included the heat dumping fans, gas mixing compressors, air filtration unit for reception hall, air filtration biofilter for digestate hall, raw waste shredder, and pasteurisation heating pump. Intermediate consumers were the feed and discharge pumps, gas holder inflation fans and the CHP water pump. There were no individual electricity meters on these and the power taken depends upon the equipment load, so cannot be calculated directly from hours run and plate capacity. Parasitic energy is therefore given as an overall figure representing the total number of $\mathrm{kWh}$ consumed on site (Table 5).

The energy required to raise the temperature of the feedstock, pasteurise the digestate and maintain the temperature of the heated tanks was calculated based on input volumes, tank dimensions and insulation values, and is given in Table 5. Temperature differentials between tanks and ambient were taken from average monthly values for the UK Meteorological Office station at Lyonshall. Feedstock materials were considered to be at ambient temperatures. It was assumed that the buffer tank, digester and pasteuriser were always full and maintained at operating temperatures.

\subsection{Energy used in digestate transport and application}

The energy required for transport and application of the digestate to land was $34350 \mathrm{kWh}$ and was calculated from actual vehicle trips made, taking into account the vehicle types used and mileages covered. Vehicle fuel efficiencies were based on emissions factors from the EU Environment Agency's Corinair database (EEA, 2002). Energy used in application of the digestate to land was calculated using tractor power efficiency conversions and estimated hours run and gave a value of $17 \mathrm{MJ}$ tonne $\mathrm{e}^{-1}$, which agrees with that quoted in Berglund and 
Borjesson (2006). More detail on the land application calculations is given in Banks et al. (in review).

\subsection{Overall energy balance}

Table 6 summarises the overall energy balance for the processing of feedstock, including delivery to the recipient sites and application to land during the study period based on the above data.

\section{Conclusions}

The specific methane yield of food waste was $98 \mathrm{~m}^{3}$ tonne $\mathrm{e}^{-1}$ wet weight or $402 \mathrm{~m}^{3}$ tonne $\mathrm{V}^{-1} \mathrm{VS}$, and productivity remained high throughout the study period. The nitrogen content led to high ammonia concentrations that buffered VFA accumulation. Net recoverable energy was 405 $\mathrm{kWh}_{\text {tonne }}{ }^{-1}$ wet weight, including digestate transport and utilisation. The mass balance was $90.4 \%$ (wet weight), and $95.7 \%$ (VS basis) allowing for loss of volatile components. Since study ended the plant has continued in successful commercial operation and provides a sustainable route for recovery of products from domestic food waste.

\section{Acknowledgements}

Funding for this project was provided by Advantage West Midlands and by Defra from the New Technologies Demonstrator Programme. The authors also gratefully acknowledge the support and assistance of Biocycle South Shropshire Ltd.

\section{References}

APHA, 2005. Standard Methods for the Examination of Water and Wastewater. 21st edition, American Public Health Association, American Water Works Association, Water Environment Federation, Washington, USA.

Angelidaki, I., Boe, K, Ellegaard, L., 2005. Effect of operating conditions and reactor configuration on efficiency of full-scale biogas plants. Water Sci. Technol. 52(1-2), 189194.

Archer, E., Baddeley, A., Klein, A., Schwager, J., and Whiting, K., 2005. MBT: A Guide for Decision Makers - Processes, Policies and Markets. Juniper Consulting Ltd, Uley, Gloucestershire, UK.

Arnold, R., Banks C.J., Chesshire, M., Foxall, M., Stoker, A., 2010. Defra Demonstration Project: Biocycle South Shropshire Biowaste Digester. Defra New Technologies Programme. Final Report. www.defra.gov.uk/environment/waste/residual/newtech/demo/documents/Biocyclefinal.pdf. Accessed 1 July 2010.

Banks, C.J., Chesshire, M., Heaven, S., Arnold, R., Lewis, L., in review. Biocycle anaerobic digester: performance and environmental benefits. Proceedings of the Institution of Civil Engineers - Waste and Resource Management.

Banks, C.J., Chesshire, M., Stringfellow, A., 2008. A pilot-scale trial comparing mesophilic and thermophilic digestion for the stabilisation of source segregated kitchen waste. Water Sci. Technol. 58(7), 1475-1480.

Banks C.J., Wang, Z., 1999. Development of a two phase anaerobic digester for the treatment of mixed abattoir wastes. Water Sci. Technol. 40(1), 69-76.

Banks, C.J. and Zhang, Y., 2010. Technical Report: Optimising inputs and outputs from anaerobic digestion processes. Defra project Code WR0212. 
http://randd.defra.gov.uk/Document.aspx? Document=WR0212_8890_FRP.pdf. Accessed 1 July 2010.

Berglund, M. and Borjesson, P., 2006. Assessment of energy performance in the life-cycle of biogas production. Biomass Bioenerg. 30(3), 254-266.

Chesshire, M., 2007. The South Shropshire biowaste digester, UK. Proceedings of the Institution of Civil Engineers - Waste and Resource Management. 160(1), 19-26.

EEA, 2002. European Environment Agency EMEP/CORINAIR Emission Inventory Guidebook (third edition). Technical Report No. 30. EEA.

El Hadj, T.B., Astals, S., Gali, A., Mace, S. Mata-Alvarez, J., 2009. Ammonia influence in anaerobic digestion of OFMSW. Water Sci. Technol. 59(6), 1153-1158.

Fricke, K., Santen, H., Wallmann, R., Hüttner, A., Dichtl, N. (2007). Operating problems in anaerobic digestion plants resulting from nitrogen in MSW. Waste Manage. 27(1), 30-43.

Hartmann, H., and Ahring, B. K., 2005. A novel process configuration for anaerobic digestion of source-sorted household waste using hyper-thermophilic post-treatment. Biotechnol. Bioeng. 90(7), 830-837.

Mata-Alvarez, J., 2003. (Ed). Biomethanization of the Organic Fraction of Municipal Solid Wastes. IWA Publishing, London.

Neilsen, H.B., and Angelidaki, I., 2008. Strategies for optimizing recovery of the biogas process following ammonia inhibition. Bioresource Technol. 99(17), 7995-8001.

Neiva Correia, C., Vaz, F., Torres, A., 2008. Anaerobic digestion of biodegradable waste operational and stability parameters for stability control. 5th IWA International Symposium on AD of Solid Wastes and Energy Crops, Tunisia.

Stretton-Maycock, D., Merrington, G., 2009. The use and application to land of MBT compost-like output - review of current European practice in relation to environmental protection. Science Report - SC030144/SR3. Environment Agency, Bristol, UK.

Ripley, L.E., Boyle, W.C., Converse, J.C., 1986. Improved alkalimetric monitoring for anaerobic digestion of high strength wastes. Journal of the Water Pollution Control Federation. 58(5), 406-411.

Wang Z.J, Banks C. J., 2003. Evaluation of a two stage anaerobic digester for the treatment of mixed abattoir wastes. Process Biochem. 38 (9), 1267-1273. 


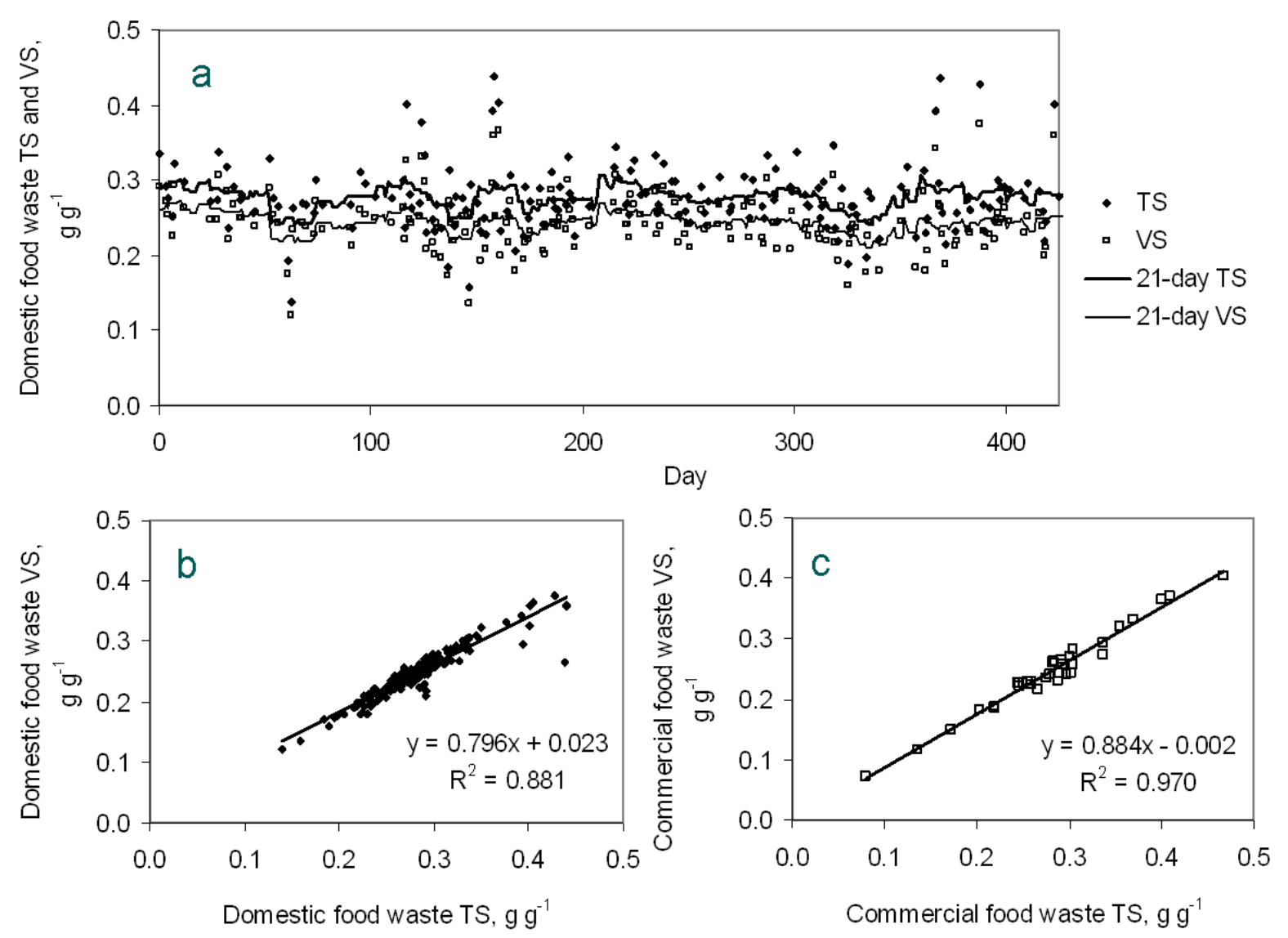

Fig. 1. TS and VS content of domestic ( $a$ and $b$ ) and commercial (c) food waste during the study period (points show average value for triplicate determinations; lines show rolling 21day averages). 

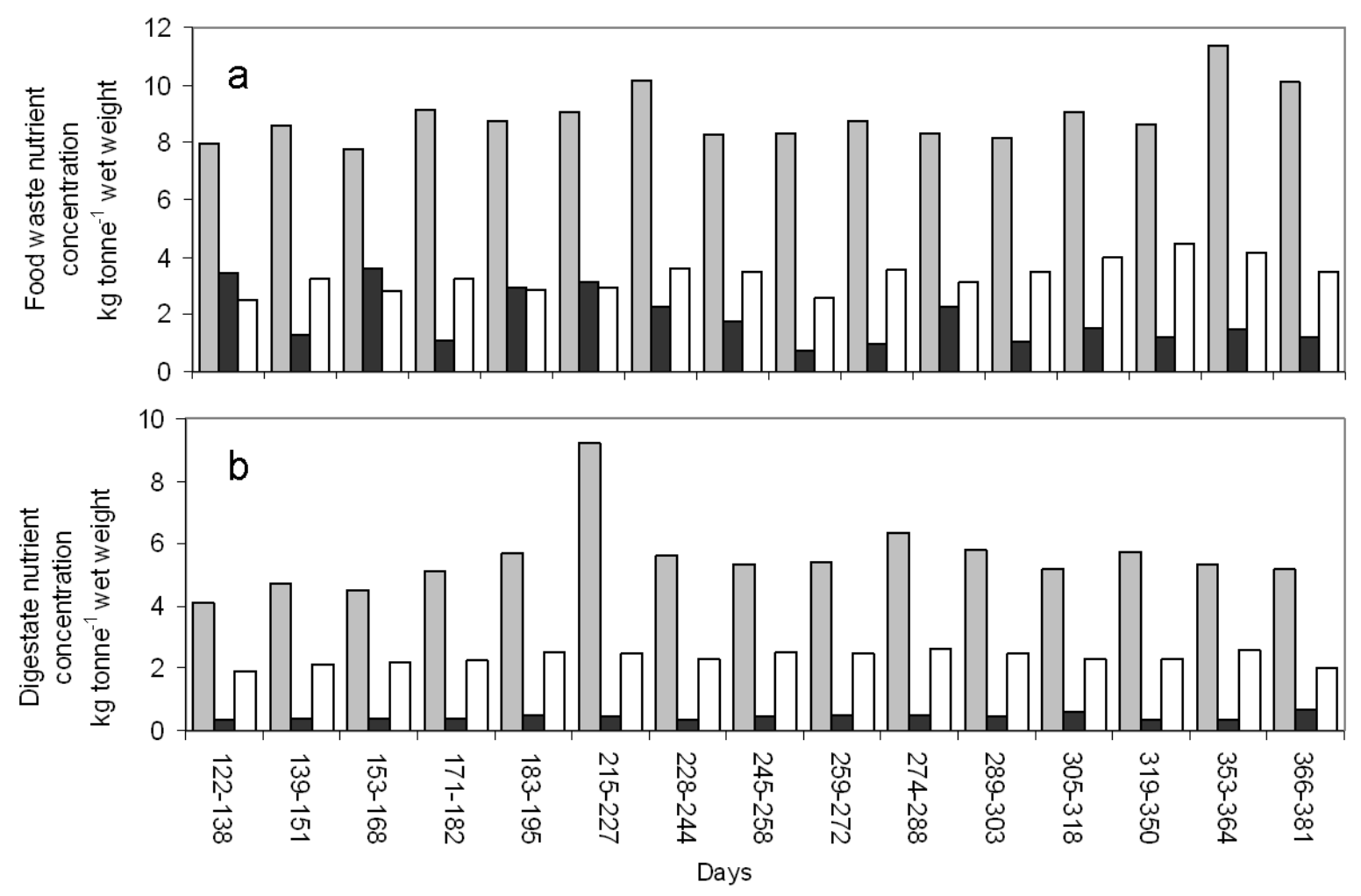

$\square$ Nitrogen $(T K N) \square$ Phosphorus $(P) \square$ Potassium (K)

Fig. 2. Variability in nutrient content of domestic food waste composite samples (a) and of digestate samples (b) during the study period 


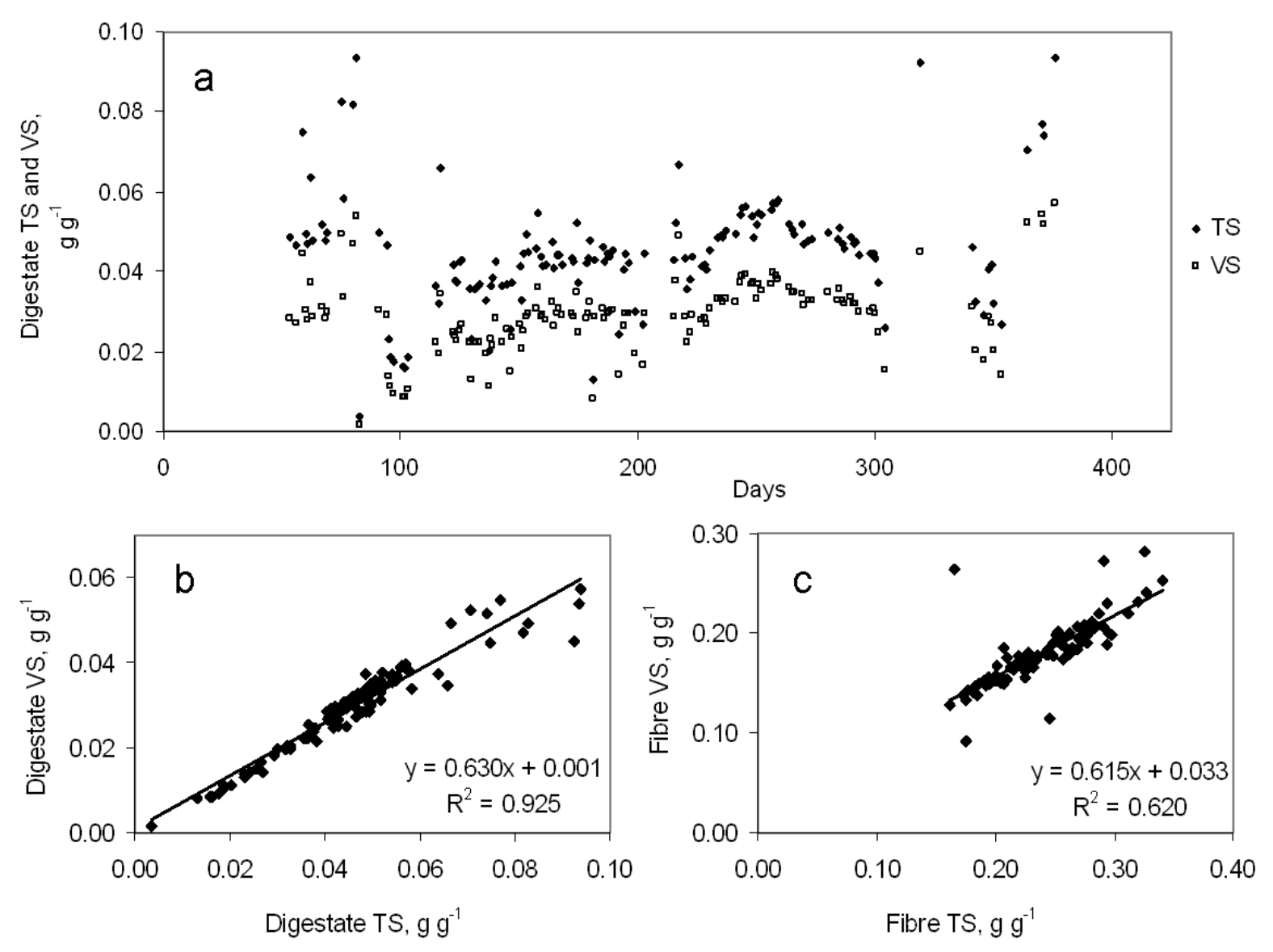

Fig. 3. TS and VS content of digestate ( $a$ and $b$ ) and fibre (c) during the study period (points show average value for triplicate determinations; note different scales for digestate and fibre) 


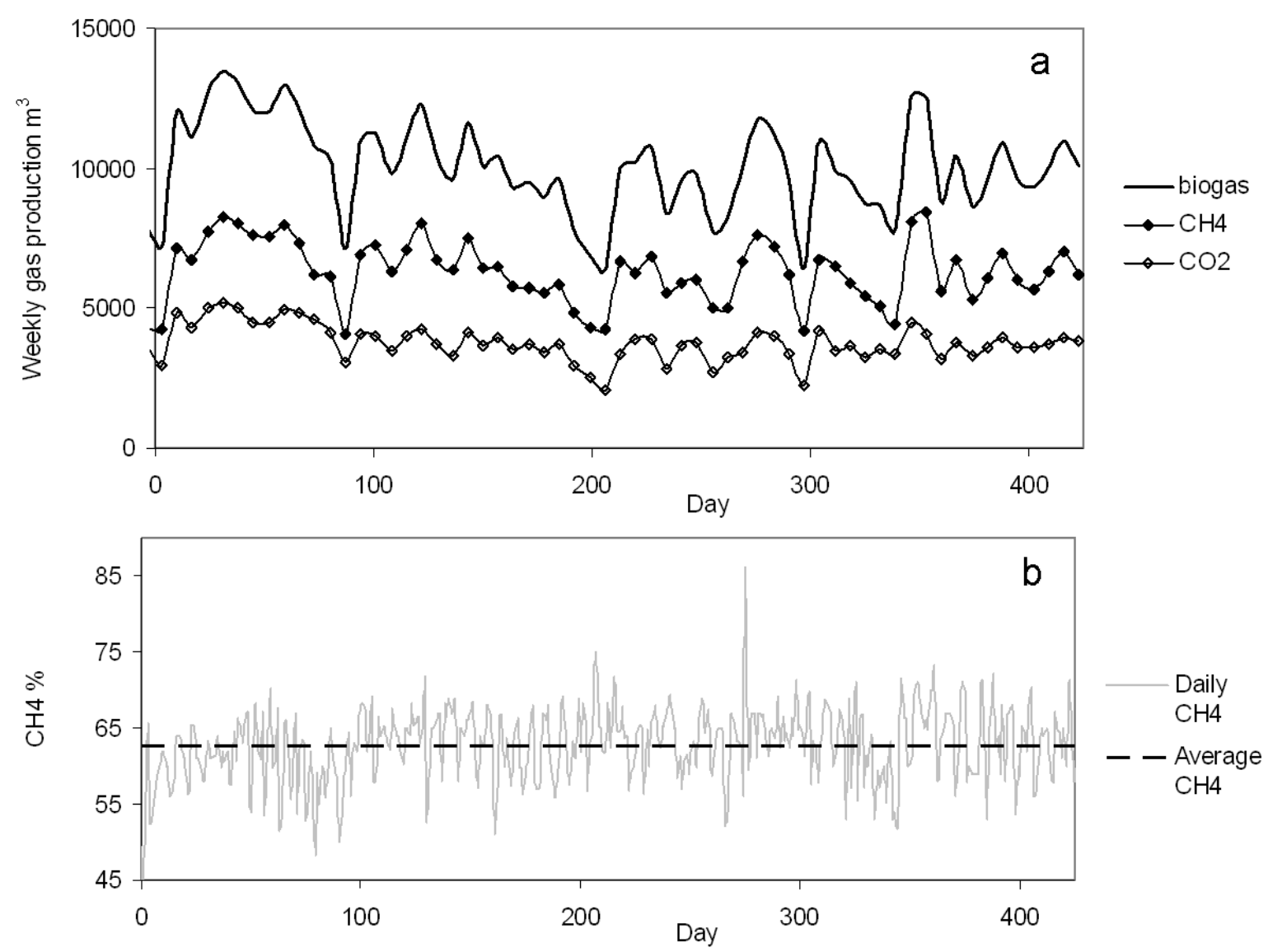

Fig. 4. Weekly gas production (a) and daily methane percentage in biogas (b) during the study period 

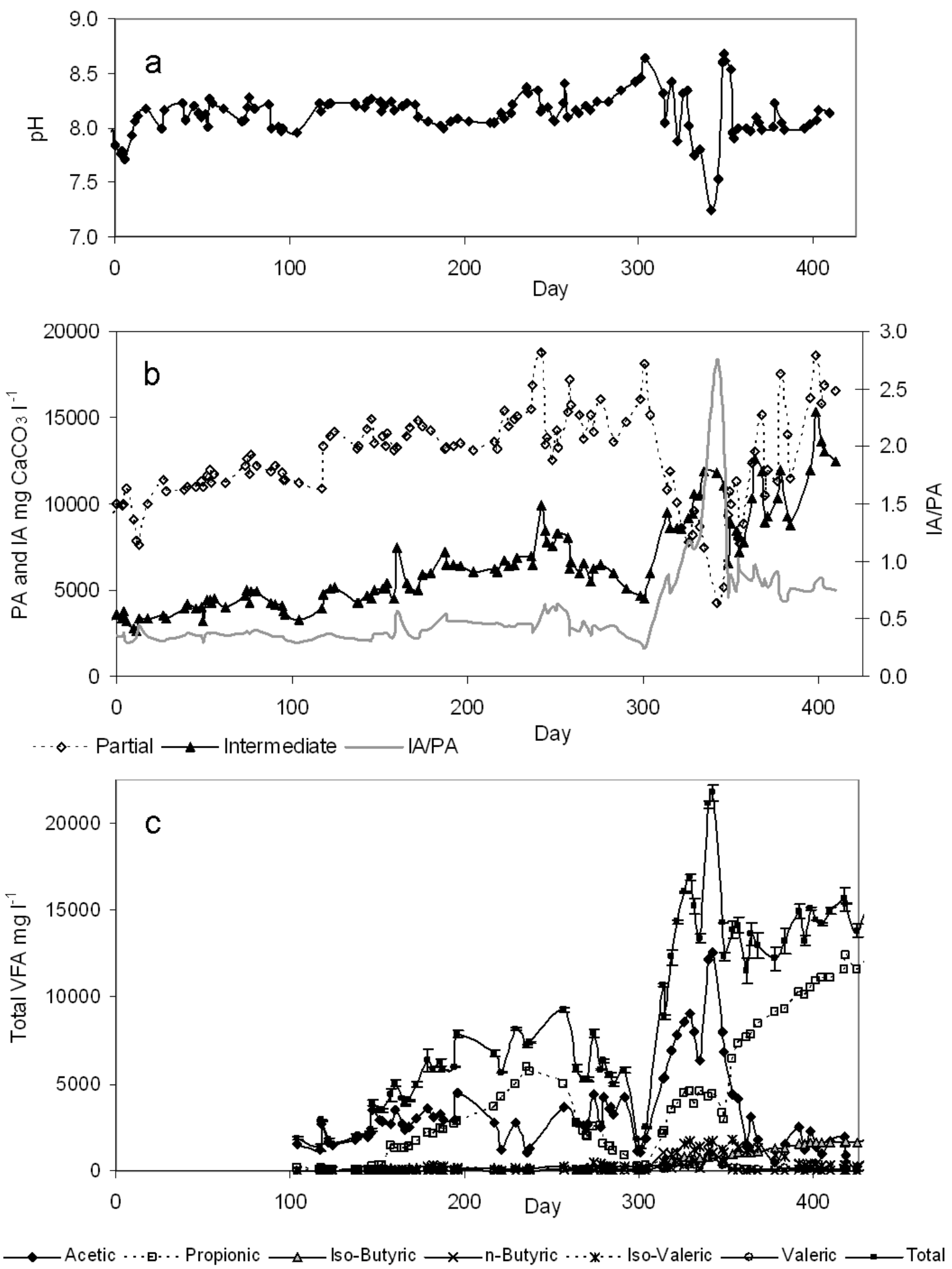

Fig. 5. Digestion parameters during the study period: $\mathrm{pH}$ (a), alkalinity (b) and VFA (c). (Hexanoic and Heptanoic acids included in total VFA but individual values not shown. Error bars on total VFA show range of duplicate determinations). 

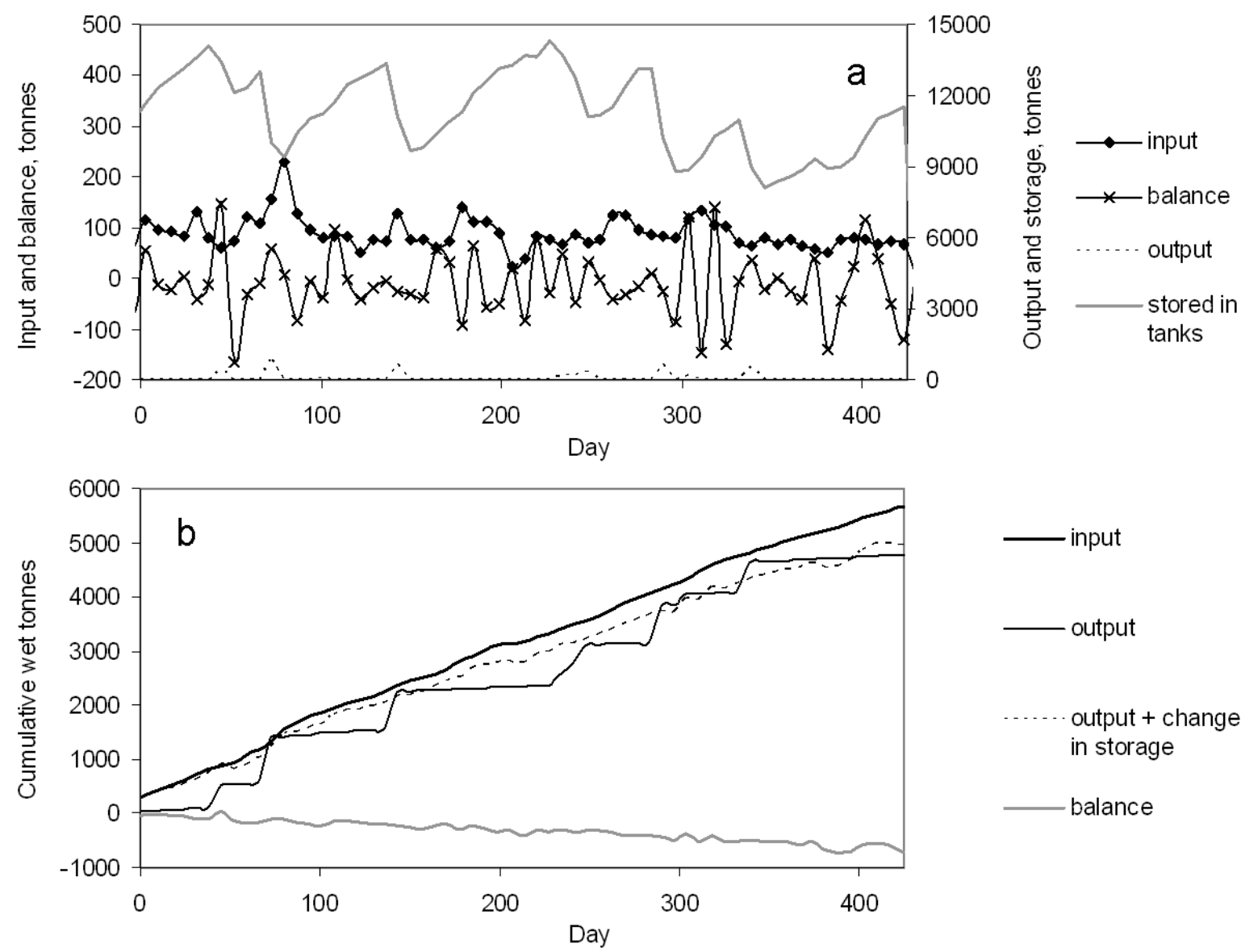

- input

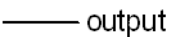

output + change in storage

- balance

Fig. 6. Mass balance (wet weight) during the study period: weekly (a) and cumulative (b) 
Table 1

Gas production parameters during mass and energy balance period

\begin{tabular}{llll}
\hline Item & Unit & Value & $\%$ \\
\hline Methane & $\mathrm{m}^{3} \mathrm{STP}$ & 385,488 & 62.6 \\
Carbon dioxide & $\mathrm{m}^{3} \mathrm{STP}$ & 229,984 & 37.4 \\
Biogas & $\mathrm{m}^{3} \mathrm{STP}$ & 615,472 & 100.0 \\
Food waste input & $\mathrm{kg} \mathrm{WW}$ & $3,936,504$ & - \\
& $\mathrm{kg} \mathrm{VS}$ & 959,209 & - \\
Specific biogas yield & $\mathrm{m}^{3}$ tonne $^{-1} \mathrm{WW}$ & 156 & - \\
& $\mathrm{m}^{3}$ tonne $^{-1} \mathrm{VS}$ & 642 & - \\
Specific methane yield & $\mathrm{m}^{3}$ tonne $^{-1} \mathrm{WW}$ & 98 & - \\
& $\mathrm{m}^{3}$ tonne $^{-1} \mathrm{VS}$ & 402 & - \\
Volumetric biogas yield & $\mathrm{m}^{3} \mathrm{~m}^{-3} \mathrm{reactor}^{\mathrm{a}}$ & 1.59 & - \\
Volumetric methane yield & $\mathrm{m}^{3} \mathrm{~m}^{-3} \mathrm{reactor}^{\mathrm{a}}$ Based on volume of digester only & 1.00 & - \\
& & &
\end{tabular}

Table 2

Mass balance for study period (wet weight)

\begin{tabular}{lll}
\hline Parameter & Unit & Value \\
\hline Food waste input & $\mathrm{kg}$ & $3,936,504$ \\
Water input (washwater) & $\mathrm{kg}$ & $1,490,000$ \\
Total input & $\mathrm{kg}$ & $5,426,504$ \\
Methane & $\mathrm{kg}$ & 275,177 \\
Carbon Dioxide & $\mathrm{kg}$ & 451,473 \\
Water vapour $_{\text {Digestate }}^{\mathrm{a}}$ & $\mathrm{kg}$ & 12,526 \\
Fibre $^{\mathrm{a}}$ & $\mathrm{kg}$ & $3,969,080$ \\
All waste leaving site & $\mathrm{kg}$ & 39,240 \\
Total output & $\mathrm{kg}$ & 35,820 \\
Wet tanks & $\mathrm{kg}$ & $4,783,315$ \\
Stored material & $\mathrm{kg}$ & 92,433 \\
Total storage & $\mathrm{kg}$ & 30,000 \\
Balance accounted for & $\mathrm{kg}$ & 122,433 \\
& $\mathrm{~kg}$ & 520,756 \\
\hline
\end{tabular}

${ }^{a}$ Any liquid digestate produced is recirculated through the process and leaves the site as whole digestate 
Table 3

Mass balance for study period (VS)

\begin{tabular}{|c|c|c|}
\hline Parameter & Unit & Value \\
\hline Food waste input & kg WW & $3,936,504$ \\
\hline Food waste VS & $\mathrm{kg} \mathrm{VS} \mathrm{kg}^{-1} \mathrm{WW}$ & 0.244 \\
\hline Total input & $\mathrm{kg} \mathrm{VS}$ & 959,209 \\
\hline Methane & $\mathrm{kg}$ VS & 275,177 \\
\hline Carbon Dioxide & $\mathrm{kg}$ VS & 451,473 \\
\hline \multirow{3}{*}{$\begin{array}{l}\text { Digestate (includes separated } \\
\text { and whole digestate) }\end{array}$} & $\mathrm{kg} \mathrm{WW}$ & $3,969,080$ \\
\hline & $\mathrm{kg} \mathrm{VS} \mathrm{kg}^{-1} \mathrm{WW}$ & 0.029 \\
\hline & kg VS & 115,521 \\
\hline \multirow[t]{3}{*}{ Fibre } & kg WW & 39,240 \\
\hline & $\mathrm{kg} \mathrm{VS} \mathrm{kg}^{-1} \mathrm{WW}$ & 0.179 \\
\hline & $\mathrm{kg} \mathrm{VS}$ & 7,040 \\
\hline \multirow[t]{3}{*}{ Reject } & kg WW & 35,820 \\
\hline & $\mathrm{kg} \mathrm{VS} \mathrm{kg}^{-1} \mathrm{WW}$ & 0.244 \\
\hline & $\mathrm{kg}$ VS & 8,728 \\
\hline \multirow{4}{*}{$\begin{array}{l}\text { Total output } \\
\text { Wet tanks }\end{array}$} & $\mathrm{kg}$ VS & 857,938 \\
\hline & kg WW & 92,433 \\
\hline & $\mathrm{kg} \mathrm{VS} \mathrm{kg}^{-1} \mathrm{WW}$ & 0.029 \\
\hline & kg VS & 2,690 \\
\hline \multirow[t]{3}{*}{ Stored material } & kg WW & 30,000 \\
\hline & $\mathrm{kg} \mathrm{VS} \mathrm{kg}^{-1} \mathrm{WW}$ & 0.179 \\
\hline & $\mathrm{kg}$ VS & 5,382 \\
\hline Total storage & $\mathrm{kg}$ VS & 8,072 \\
\hline \multirow[t]{2}{*}{ Balance } & $\mathrm{kg} \mathrm{VS}$ & 93,198 \\
\hline & $\%$ & $90.3 \%$ \\
\hline
\end{tabular}

Table 4

Electrical and heat outputs from the CHP plant during the study period

\begin{tabular}{llll}
\hline Parameter & Unit & Value & $\%$ \\
\hline CHP gross energy $^{\text {a }}$ & $\mathrm{kWh}$ & $2,781,481$ & $100.0 \%$ \\
CHP gross electrical output & $\mathrm{kWh}$ & 890,074 & $32.0 \%$ \\
CHP parasitic electrical requirement & $\mathrm{kWh}$ & 37,728 & $1.4 \%$ \\
CHP net electrical output & $\mathrm{kWh}$ & 852,346 & $30.6 \%$ \\
CHP gross heat output & $\mathrm{kWh}$ & $1,891,407$ & $68.0 \%$ \\
CHP recoverable heat output & $\mathrm{kWh}$ & $1,474,185$ & $53.0 \%$ \\
CHP waste heat & $\mathrm{kWh}$ & 417,222 & $15.0 \%$ \\
\hline
\end{tabular}

${ }^{a}$ Calculated as electrical output divided by conversion efficiency taken as $32 \%$ 
Table 5

Breakdown of process energy requirements

\begin{tabular}{lll}
\hline Parameter & Unit & Value \\
\hline CHP electrical parasitic & $\mathrm{kWh}$ & 37,728 \\
Rest of plant parasitic & $\mathrm{kWh}$ & 232,694 \\
Total electrical parasitic & $\mathrm{kWh}$ & 270,422 \\
\% of gross electrical output & & $30.4 \%$ \\
Heat requirement to raise feedstock temperature & $\mathrm{kWh}$ & 202,674 \\
Heat requirement for pasteurisation & $\mathrm{kWh}$ & 150,709 \\
Heat requirement to maintain tank temperatures & $\mathrm{kWh}$ & 92,951 \\
Total parasitic heat requirement & $\mathrm{kWh}$ & 446,334 \\
\% of recoverable heat & & $30.3 \%$ \\
\hline a Total electrical parasitic, divided by CHP gross electrical output from Table 4
\end{tabular}

Table 6

Overall energy balance

\begin{tabular}{|c|c|c|}
\hline Parameter & Unit & Value \\
\hline CHP net electrical output & $\mathrm{kWh}$ & 852,346 \\
\hline Parasitic electrical requirement of process plant & $\mathrm{kWh}$ & 232,694 \\
\hline Net energy output as electricity & $\mathrm{kWh}$ & 619,652 \\
\hline Recoverable heat output from CHP & $\mathrm{kWh}$ & $1,474,185$ \\
\hline Parasitic heat requirement of plant & $\mathrm{kWh}$ & 446,334 \\
\hline Net energy output as heat & $\mathrm{kWh}$ & $1,027,851$ \\
\hline CHP natural gas used & $\mathrm{kWh}$ & 18,413 \\
\hline Energy required for digestate use & $\mathrm{kWh}$ & 34,350 \\
\hline Total potentially recoverable energy (heat and electricity) ${ }^{\mathrm{a}}$ & $\mathrm{kWh}$ & $1,594,740$ \\
\hline Total potentially recoverable energy per wet tonne of food waste & $\mathrm{kWh}$ & 405 \\
\hline
\end{tabular}

${ }^{\mathrm{a}}$ Includes heat energy generated but not used at the time of the study 